\title{
WINO I TECHNOLOGIA PRODUKCJI WIN W GALLII NARBONENSIS W II W P.N.E. - II W. N.E.
}

\author{
WINE AND THE WINES PRODUCTION TECHNOLOGY \\ IN GALLIA NARBONENSIS \\ IN THE 2ND CENTURY BC B.C. - 2ND CENTURY A.D.
}

\author{
Agnieszka Góralczyk \\ https://orcid.org/0000-0002-6900-1488 \\ Instytut Archeologii i Etnologii PAN \\ AL. Solidarności 105, 00-140 Warszawa \\ agnieszka785@gmail.com
}

\begin{abstract}
The article describes the process of making wine in antiquity and tools used for it. It presents wine production in the Roman province of Gallia Narbonensis based on historical and archaeological sources.
\end{abstract}

KEY WORDS: Gallia Narbonensis, wine presses, Columella, Magon, wine, defrutum, sapa, passum, villa

\section{TECHNOLOGIA WYTWARZANIA WINA}

Wino stanowiło w starożytności nie tylko przedmiot handlu i ceniony trunek, ale stało się symbolem pozycji i bogactwa dla niektórych grup społecznych oraz elementem rytualnych libacji podczas ofiar składanych bóstwom. O winie można znaleźć wiele informacji w źródłach pisanych: w literaturze greckiej i rzymskiej, zarówno w prozie, jak i poezji, tekstach historiograficznych i utworach literackich ${ }^{1}$. Nie moż-

\footnotetext{
${ }^{1}$ Niektóre z nich stanowią podręczniki rolnictwa i ogrodnictwa, obejmujące także uprawę winorośli i produkcję wina, jak w przypadku prac: De agricultura Katona Starszego (żyjącego w latach 234-149 p.n.e.), Rerum rusticarum libri III Warrona (116-27 rok p.n.e.), De re rustica Kolumelli (I w. n.e.) oraz
} 
na także zapominać o związkach wina z takimi dziedzinami, jak rolnictwo (rozwój uprawy winnej latorośli) czy rzemiosło (produkcja naczyń ceramicznych, m.in. amfor). Znaleziska archeologiczne amfor i analiza wyposażenia grobowego pod względem znajdującej się w nim ceramiki pokazują, że wino znano w Lacjum od końca VIII w. p.n.e. i rozwój uprawy winnej latorośli datuje się od połowy VII w. p.n.e. (Sáez Fernández, 1999, s. 36).

Wytwarzanie wina w starożytności nie było rzeczą łatwą. Aby uzyskać trunek dobrej jakości, należało wykazać się nie tylko znajomością jego produkcji, ale doświadczeniem w tej dziedzinie, najlepiej uzyskanym przez wieloletnią praktykę. Towarzyszyło temu wiele pomyłek i tak naprawdę jakość wina i metody jego wytwarzania zmieniały się z pokolenia na pokolenie wraz z przekazywaną sobie wiedzą. Jak łatwo się domyślić, niektórzy z producentów wina osiągnęli większą biegłość w uprawie winorośli i starali się udoskonalać proces produkcji na tyle często i z dobrym skutkiem, że ich wino było lepsze i sprzedawało się z większym zyskiem (Tchernia, Brun, 1999, s. 112).

Kolumella ${ }^{2}$ w 21 rozdz. XII księgi De re rustica opisywał sposób, który bez wysiłku miał doprowadzić do dojrzałości zacier z moszczu winogronowego. Powoły-

Opus agriculturae Palladiusza (IV/V w. n.e.). Zawierają praktyczne porady, podobnie jak traktaty autorstwa dwóch Galów: Juliusza Atticusa i Juliusza Graecinusa, powstałe pod koniec rządów Tyberiusza (I w. n.e.). Inne opisują scenki rodzajowe i w mniej lub bardziej żartobliwy sposób przedstawiają skutki spożywania mocnych trunków - poezja: Amores Owidiusza(43 rok p.n.e.-18 lub 17 rok n.e.), Sermones Horacego (65-8 rok p.n.e.), elegie miłosne Propercjusza (około 50 - między 15 a 2 rokiem p.n.e.), Epigrammaton liber Marcjalisa (ok. 40-104 rok n.e.) Dostarczają przy tym takich informacji, jak miejsce produkcji opisywanego wina, przytaczają jego nazwę lub ocenę jego smaku i jakości. Źródła o charakterze encyklopedycznym, jak prace: Naturalis historia Pliniusza Starszego (23-79 rok n.e.), Noctes Atticae Aulusa Gelliusza z II w. n.e. czy Saturnalia Makrobiusza z (IV/V w. n.e.) zawierają różnorodne wiadomości albo o winie, albo o właściwościach winorośli. Prace: Moralia Plutarcha (przed 50 - po 120 rok n.e.), Epistulae ad Atticum, Epistulae ad Familiares i De re publica Cycerona (106-43 rok p.n.e.), relacjonujące współczesną autorom rzeczywistość, nie pomijają wzmianek o spożywaniu wina czy też popularności, jaką cieszyły się dane trunki, zaś De medicina libri VIII, kompendium wiedzy medycznej Korneliusza Celsusa, powstała w czasach rządów Tyberiusza, przytacza przykłady zastosowania wina w leczeniu wielu chorób (ale też uwagi o uprawie winorośli) (zob. Świderkówna, red., 1990). Po podbiciu Kartaginy przez Rzymian w 146 roku p.n.e. senat zalecił przetłumaczenie traktatu kartagińskiego agronoma Magona o rolnictwie ze względu na zawarte w nim porady dotyczące nowych sposobów uprawy winnej latorośli i wytwarzania wina. Nie zachował się do naszych czasów w całości, a jedynie we fragmentach przytaczanych przez innych autorów (zob. Sáez Fernandez, 1999, s. 41).

${ }^{2}$ Kolumella (Lucius Iunius Moderatus Columella), pochodzący z Gades na półwyspie Iberyjskim i żyjący w I w. n.e., po zakończeniu działalności publicznej osiadł w majątku wiejskim pod Ardeą w Lacjum. Napisał tam znakomity podręcznik De re rustica omawiający zagadnienia dotyczące prowadzenia gospodarstwa. Ze względu na zrozumiały i dokładny język jego pracy oraz porady oparte na własnym doświadczeniu, dzieło Kolumelli zachowało się w całości, wielokrotnie wydawane do połowy XVII w. Co ważne, autor powoływał się w nim na prace wcześniejsze Atticusa, Graecinusa, Katona Starszego oraz Warrona, a także Magona. Opisał m.in. w De re rustica zagadnienia dotyczące uprawy winorośli, jej rodzajów i prowadzenia winnicy (III-V księga) oraz produkcji wina (XII księga) (zob. Świderkówna, 1990, s. 147). 
wał się przy tym na doświadczenia swojego wuja uprawiającego winorośl w Betyce (Mikołajczyk, 1991, s. 152-172; Hedberg, Lundström, Josephson, 1968, s. 30-53). Opisy te są wiarygodne. A. Tchernia zebrał różne porady Kolumelli dotyczące wytwarzania win i wypróbował je w praktyce, używając winogron uprawianych na nizinie w Mas des Tourelles. Kolumella zwracał uwagę na pochodzenie owoców winogron. W zależności od tego, czy rosły na nizinach, czy pagórkowatym terenie dodawano do defrutum (wywaru z moszczu) sporządzony z ich moszczu zacier, ale $\mathrm{w}$ innych proporcjach (1/48 do win $\mathrm{z}$ winogron $\mathrm{z}$ terenów górzystych oraz $1 / 32$ z nizinnych). W przypadku wilgotnego winobrania Kolumella radził użyć do $1 / 24$ zacieru. W eksperymencie wzięto pod uwagę różnice klimatyczne między dzisiejszą Langwedocją a starożytną centralną Italią, a jako soli użyto stężonej wody morskiej lub soli, ale niewyprażanej. Efekty nie zawiodły oczekiwań i uzyskano wino w takiej postaci jak w starożytności. Do zacieru dodawano po dwóch dniach od rozpoczęcia fermentacji 1/32-1/24 aromatyzowanego defrutum - cztery dni od rozpoczęcia fermentacji 0,6 centylitra/litr wody morskiej stężonej w $1 / 3$ i równoważne około 0,7 soli (chlorek sody i inne) na litr, w tym samym czasie 0,04 mililitra/ litr lub później po obliczeniu gęstości 0,03 gramów/litr kozieradki pospolitej macerowanej w winie, suszonej i pokruszonej, a pod koniec fermentacji 0,7 gramów/litr gipsu. Kozieradka pospolita zmieszana z zacierem nadawała przygotowywanemu winu smak. Defrutum, sól i gips stanowiły podstawowe składniki używane w starożytności w procesie produkcji wina. Gips służył do klarowania, ale ponieważ zmienia smak, dzisiaj nie stosuje się go w produkcji win dobrych, co najwyżej stołowych lub z drugiego tłoczenia. Winną latorośl uprawiano raczej na glebach wapiennych, co odbijało się na ich smaku. Aby wino nie nabrało wskutek tego gorzkiego sma$\mathrm{ku}$, wytrącano ewentualny nadmiar wapienia. Czysta siarka lub siarczany pomagały w klarowaniu i zatrzymywaniu fermentacji w winach o wysokiej zawartości cukru, aby w wyniku kolejnej fermentacji nie powstał ocet. Smak wygaszano ziołami, a powstały osad albo wyrzucano, albo stosowano jako przyprawę kuchenną.

Warron, Kolumella, Pliniusz Starszy i Palladiusz opisują i definiują w swoich pracach defrutum i prawie dla niego synonimiczną sapa. Chodzi o wywar powstały z moszczu winnego jako zacier poddawany odtlenieniu przez powolne zagotowywanie w temperaturze wrzenia, do ćwierci, jednej trzeciej, połowy lub dwóch trzecich podstawowej objętości. W różny sposób o defrutum piszą różni autorzy. Kolumella wspomina o defrutum, mając na myśli zagęszczony zacier. Pozostawia również rady dotyczące winobrania, takie jak: zbieranie winogron do produkcji wina podczas nowiu księżyca, gotowania ich moszczu w ołowianych naczyniach wysmarowanych oliwą, żeby nie przypalała się zawartość, unikania naczyń zaśniedziałych, które psują smak wyrabianego wina. Kiedy gotowane wino spieniło się, należało dodać gotowanej masie aromatu. Kolumella radził ugotować kilka pigw, dorzucić kłącze irysa - pół $\mathrm{kg}$ do 90 amfor, czyli 0,18 gramów/litr, w takiej ilości jak kozieradkę pospolitą oraz marzycę (schoenus).

Odtlenienie zacieru we wrzącej temperaturze podczas gotowania skupia cukry i kwasy. Połączenie defrutum z zacierem prowadzi do powiększenia zawartości al- 
koholu i kwasów, co wpływa na wyrabiany trunek konserwująco. Powiększenie kwasowości różni się jednak od procesu scukrzania młodego wina przed fermentacją. Wino było przyprawiane podczas jego wyrobu, aromatyzowane i dosalane. Kolumella radził dodać w tym celu wodę morską. $1 / 48$ wody morskiej w stosunku do całości gotowanej masy dosalało ją 0,76 gramów/litr. W przypadku sproszkowanej, wyprażonej soli 0,52 gramów/litr. Ilości do dosolenia podane przez Kolumellę są umiarkowane, mogły one sięgać w zależności od masy 1 gram/litr (Tchernia, Brun, 1999, s. 112-114).

Kozieradka pospolita stosowana jako aromatyzator wina ma właściwości antyseptyczne. W zachodniej części basenu Morza Śródziemnego liści tej rośliny używano jako paszy dla zwierząt. Znalazła również zastosowanie w medycynie jako element diety wzmacniającej. Gips, o którym pisze Kolumella, dodawano w niewielkiej ilości do wina nie tylko w starożytności, ale i w czasach nowożytnych w niektórych rejonach Europy, np. na południu Francji, dopóki nie zakazano tego w 1907 roku. Ów gips, czyli siarczan wapnia, pomagał sklarować i zakonserwować wina, w przypadku czerwonych win z południa spowolnić fermentację i nadać im cierpki smak. W 1880 roku we Francji regulowano ten dodatek na 2 gramy/litr. Gips w połączeniu $\mathrm{z}$ dwuwinianem potasu zawartym w przygotowywanym winie tworzy siarczan potasu, winian wapna i kwas winowy. Winian wapna klaruje wino, a kwas winowy zwiększa kwaśność wina. Winogrona uprawiane w ciepłych krajach przydają wyrabianym winom mniejszą cierpkość niż te z chłodniejszych. Zawsze trzeba było wziąć to pod uwagę w czasie produkcji i doprawiania wina. Dodawanie gipsu do wina było w starożytności powszechnie praktykowane w najbardziej wysuniętych na południe rejonach Europy. Od końca IV w. p.n.e., jak pisze Tcheofrast, używano gipsu w produkcji win w Italii. O zastosowaniu gipsu wspomina Kolumella. Pliniusz Starszy pisze o jego użyciu w odniesieniu do Afryki, Palladiusz zaś Grecji (Tchernia, Brun, 1999, s. 115-117).

W XII rozdz. De re rustica Kolumella przytacza także pełny przepis wina rodzynkowego (passum), zaczerpnięty z traktatu Magona, powołując się na jego opinię, że jest to doskonały trunek. Według kartagińskiego agronoma należy zebrać wczesne winogrona, gdy są one dość dojrzałe, odrzucić spleśniałe lub uszkodzone owoce, a następnie wysuszyć je, pamiętając, aby nie kłaść ich na ziemi oraz okryć dla ochrony przed poranną rosą. Po wysuszeniu trzeba porozdzielać grona na pojedyncze owoce i wrzucić je do beczki lub dzbana na wino, aby samorzutnie sfermentowały (maceracja). Szóstego dnia powstały moszcz winny wkłada się do tłoczni na wino i usuwa pestki. Po ugnieceniu skórek winogronowych dodaje się do nich bardzo świeży moszcz pochodzący z innych winogron wysuszonych przez 3 dni na słońcu, a następnie miesza się wszystko razem w jedną masę i wkłada do tłoczni. Powstałe wino rodzynkowe $\mathrm{z}$ drugiego tłoczenia należy jak najszybciej umieścić w szczelnie zamkniętych naczyniach. Po zakończeniu fermentacji, 20 lub 30 dni później, trzeba je odcedzić do innych naczyń i dodać natychmiast gips pod pokrywki oraz przykryć go skórkami (Greene, 1996, s. 315). 


\section{ŹRÓDŁA ARCHEOLOGICZNE - ŚWIADECTWA PRODUKCJI WIN}

\section{Rozwój technologii wytwarzania wina w basenie Morza Śródziemnego}

Próby odtworzenia procesu wytwarzania wina opierają się nie tylko na źródłach pisanych, ale i znaleziskach archeologicznych, takich jak pozostałości tłoczni na wino, pras owocowych i kadzi oraz zbiorników na moszcz i sok winny. Zanim produkcja wina w zachodniej części basenu Morza Śródziemnego osiągnęła masową skalę w czasach Cesarstwa Rzymskiego, głównym producentem wina byli Grecy, słynący z wyrobu trunków świetnej jakości. Rzymianie przejęli technologię wytwarzania wina od Greków. Jednakże to nie Grecy zapoczątkowali produkcję wina we wschodniej części basenu Morza Śródziemnego.

Początki uprawy winnej latorośli na Bliskim Wschodzie sięgają 5 tys. lat p.n.e. (tereny obecnego Iranu, Kaukaz). Wiemy, że miażdżono wówczas winogrona i otrzymany sok poddawano procesowi fermentacji w glinianych dzbanach. Nie odkryto we wszystkich tych pojemnikach śladów winianu potasu i trzeba byłoby bardzo się upierać, żeby uznać owe naczynia za pierwowzory obecnie używanych kadzi żaroodpornych do wyrobu wina. Wytwarzaniem wina zainteresowały się różne ludy, takie jak np. Hetyci, Asyryjczycy i Egipcjanie. Znaleziska archeologiczne z terenu Palestyny wyraźnie wskazują, że od III tysiąclecia p.n.e. (okresu Późnego Państwa) do IV w. p.n.e. (czasów przejęcia od Greków innych metod produkcji) winogrona ugniatano nogami w basenach skalnych lub, tak jak w Egipcie, murowanych. Egipcjanie używali tzw. tłoczni skręcającej do uzyskania soku z moszczu winnego ${ }^{3}$.

Ta prymitywna metoda została zastąiona wydajniejszymi i szybszymi sposobami produkcji wina. Co ciekawe, na stanowisku Suveret, blisko Fréjus, leżącym na obszarze rzymskiej Galii Narbonensis, znaleziono resztki worka, w którym wytłaczano sok winny podobnie jak w Egipcie oraz pozostałości bardzo prostej w obsłudze tłoczni wraz ze zbiornikiem. Pozostałe znaleziska z rejonu, w którym znajduje się Suveret (datowane na I-II w. n.e.), świadczą o bardziej zaawansowanej technologii wytwarzania wina. Budzi zdziwienie, dlaczego na tym stanowisku nie zaniechano tak prymitywnej metody produkcji, nawet mimo konkurencji okolicznych wytwórni (Tchernia, Brun, 1999, s. 88).

Rzymianie przejęli sposób wyrabiania wina od Greków. W północnej części basenu Morza Śródziemnego urządzenia do produkcji wina udoskonalano bardzo różnorodnie. Na Krecie i Cyprze w III i II tysiącleciu p.n.e. używano głównie

${ }^{3}$ Do worka sporządzonego z tkaniny wrzucano wytłoczyny z miażdżonych nogami winogron. Po jego zapełnieniu dwa końce worka zawieszano na dwóch grubych drągach drewnianych, które ciągnęło potem czterech mężczyzn, każdy w swoją stronę. Powstający w ten sposób sok ściekał do glinianego naczynia, aby potem fermentować w murowanej kadzi. Po sfermentowaniu wino przelewano do małych amfor, ale zakorkowywano dopiero po zakończeniu odgazowywania sporządzonego napoju (zob. Tchernia, Brun, 1999, s. 48). 
urządzeń ceramicznych. Winogrona miażdżono w cebrzyku z terakoty umieszczonym nad zbiornikiem i zaopatrzonym w podstawkę. Z dziobka cebrzyka spływał do dzbanka winny moszcz. Wytłoczyny mogły być uzyskiwane w taki sposób jak w Egipcie, ale chętniej posługiwano się tłocznią wyposażoną w dźwignię. W dźwignię były zaopatrzone także tłocznie używane do wyrobu masy z oliwek. Tłocznie oliwne znajdowane w Ougarit w Syrii, Kommos na Krecie, Kalavasos i Maroni na Cyprze składały się z kamiennych stołów z koszami, w które zbierano masę ze zgniecionych oliwek, uzyskiwaną za pomocą drewnianego bala umieszczonego w ścianie pomieszczenia, w którym znajdowała się prasa. Możliwe, że urządzenia o podobnej konstrukcji służyły do wyrobu wina, ale żadne źródła archeologiczne nie poświadczają tego twierdzenia na czasy starsze niż VI w. p.n.e. (Tchernia, Brun, 1999, s. 48-50).

Zły stan zachowania pozostałości tłoczni lub pras odkrywanych w czasie badań archeologicznych często uniemożliwia prawidłową identyfikację znalezisk, czego przykładem są kamienne bloki z II w. n.e. znalezione w Forum Voconii w Le Cannet-des-Maures (Var) (w starożytnej Galii Narbonensis). Nie ma wątpliwości, że stanowiły część tłoczni. Niestety trudno jednoznacznie stwierdzić, czy było to urządzenie do wyrobu oliwy, czy wina (Brun, 2001, s. 75).

Greckie wazy attyckie czarnofigurowe i czerwonofigurowe z VI i V w. p.n.e. ozdobione są przedstawieniami drewnianych kadzi do ugniatania winogron, dzbanków na moszcz i tłoczni wyposażonych w drewniany bal zawieszony nad kamiennymi zbiornikami (,koszami”). Tłocznie greckie udoskonalono w późniejszych czasach, zastępując kamienne zbiorniczki zbiornikiem wykonanym z jednorodnego kamienia i przytwierdzonym powyżej niego kołowrotem. Kołowrót, ciągnąc sznury konopne lub skórzane, podnosił i opuszczał pień drzewa wytłaczający winne wytłoczyny.

W Italii czasów Republiki rzymskiej przeciwwagą dla opisywanego kołowrotu stał się drugi kołowrót zamocowany między dwoma słupami wbudowanymi w murowaną konstrukcję. Urządzenia do wyrobu wina z tej epoki tworzą wielkie i ciężkie tłocznie, duże kadzie do zlewania i odcedzania moszczu winogronowego i uzupełniające tok produkcji piwnice wypełnione amforami wina. Od 2 połowy I w. p.n.e. stopniowo zastępowano kołowroty śrubami. W ciągu I w. n.e. śruby te służyły nie do manewrowania ciężarem dźwigni, ale do bezpośredniego tłoczenia wytłoczyn jak imadło. Śruba stała się pożytecznym udoskonaleniem, ale pomysł ten przyjmował się nierównomiernie i powoli. We wczesnym Cesarstwie Rzymskim nie we wszystkich jego rejonach znano i używano tego typu tłoczni. W Afryce nigdy nie posługiwano się tłoczniami śrubowymi, w przeciwieństwie do Galii, w której te urządzenia były bardzo popularne. Wiemy według jakich zasad funkcjonowały tłocznie i prasy do wyrobu wina i co stanowiło nieodzowne części ich konstrukcji, ale trudno precyzyjnie je odtworzyć i mieć pewność całkowitej zgodności z antyczną rzeczywistością. Źródła pisane, archeologiczne i ikonograficzne, nie dostarczają nam na tyle dużo szczegółowych informacji, byśmy mogli zrekonstruować wszystkie rodzaje tłoczni na wino (Tchernia, Brun, 1999, s. 50). 


\section{Urządzenia do produkcji wina używane w Galii Narbonensis}

W I-II w. n.e. w Galii Narbonensis produkowano wino, wykorzystując do tego dwa rodzaje tłoczni: wyposażonej w dźwignię i kołowrót (używanej także w okresie Republiki rzymskiej) oraz działającej dzięki dźwigni z obciążeniem stanowiącym przeciwwagę i kołowrotowi.

Pierwszy rodzaj stanowiło urządzenie składające się z dużego pnia drzewa umieszczonego poziomo i służącego jako dźwignia. Po jednej stronie znajdował się on między dwoma masywnymi słupami z drewna, a po drugiej mógł być poruszany za pomocą sznurów zamontowanych w kołowrocie umieszczonym również między dwoma drewnianymi balami. Niektóre prasy potrzebowały mocnych fundamentów, solidnie umieszczonych w podłożu, czego przykładem są znaleziska ze stanowisk w Roussiveau (Saint-Raphaël) i w Saint-Aygulf (Fréjus) (Brun, 2001, s. 85). Rekonstrukcja odkrytych pozostałości tego typu tłoczni nie pozostawia żadnych wątpliwości. Podobne urządzenia wyposażone w dźwignię i kołowrót opisał Katon Starszy (234-149 rok p.n.e.). O ich popularności świadczą zbliżone budową prasy, pochodzące z tej samej epoki i znalezione w gospodarstwie, w którym wyrabiano oliwę z oliwek w L'Ormeau w Taradeau i fermach z okolic Fréjus (Plan Guinet, Roussivau) (Tchernia, Brun, 1999, s. 88-89).

W I w. n.e. zaczęto wykorzystywać tłocznie drugiego rodzaju, tzn. wyposażone $\mathrm{w}$ dźwignię z obciążeniem stanowiącym przeciwwagę. Stały się konkurencyjne dla pras pierwszego rodzaju, ponieważ były wydajniejszymi i bezpieczniejszymi urządzeniami. Kołowrót umieszczony między dwoma słupami stanowiącymi część ściany budynku zabezpieczał ogromny, prostokątny blok z kamienia. W czasie obsługiwania kołowrotu obciążenie przenosiło się na koniec dźwigni w oczekiwaniu na nacisk wywierany przez ciężar zwielokrotniony przez ramię dźwigni działającej przy podstawie urządzenia (Brun, 2001, s. 85-86). Pierwsze tłocznie wyposażone w tego typu dźwignię pojawiły się w czasach rządów Flawiuszy (Wespazjana - 69-79 rok n.e., Tytusa - 79-81 rok n.e. i Domicjana - 81-96 rok n.e.) (Tchernia, Brun, 1999, s. 88) i najczęściej występowały od końca I w. n.e., zwłaszcza w dużych wiejskich posiadłościach, takich jak Les Toulons, Saint-Martin i Le Grand Loou (Brun, 2001, s. 86).

Prasy z dźwignią i przeciwwagą łatwo było przekształcić w tłocznie wyposażone w śrubę (kołowrót zastępowano śrubą). Od 2 połowy I w. p.n.e. w Italii zaczęto stosować śrubę jako element konstrukcji prasy do tłoczenia winogron. Wykorzystywanie tego typu urządzeń nie stanowiło powszechnego zjawiska w Galii Narbonensis aż do II w. n.e. Tłoczni ze śrubą używano głównie w III w. n.e. W dużych posiadłościach ziemskich np. Les Toulons, Saint-Martin i wśród urządzeń do wyrobu wina z dzielnicy Régine w Puy-Sainte-Réparade (Bouches-du-Rhône) oraz w mniejszych wiejskich gospodarstwach np. Le Théron (Cannet-des-Maures), Kierbon (Trets) przekształcono prasy w opisywane tłocznie ze śrubą. W niektórych przypadkach kamienne obciążenie przeciwwagi zastępowano blokami o zaokrąglonych lub cylindrycznych rogach, żeby łatwiej było kręcić, naciskając pręty umieszczone w śrubie, np. w Les Toulons, Agay (Saint-Raphaël), La Bouverie (Roquebrune-sur-Argens). Dotychczas nie znale- 
ziono szczątków śruby umieszczonej bezpośrednio w prasie, ale trzeba szczególnie dobrych warunków, żeby się zachowała i przetrwała do naszych czasów (Brun, 2001, s. 85-86).

Winogrona wytłaczano w zbiorniku wybetonowanym w ziemi i zaopatrzonym w kamienny lub ołowiany wylot. Tego typu kadzie znaleziono w mniejszych gospodarstwach wiejskich, takich jak: Barresse, L'Ormeau oraz w większych: Le Grand Loou, Les Toulons, Saint-Martin. W jednym przypadku, w Sivier, zbiornik wykuto w skale. Tłocznie i prasy mogły stanowić część tego samego urządzenia z tą samą kamienną płytą do podnoszenia (jak np. w Les Toulons) i znajdować się w osobnym pomieszczeniu przeznaczonym do produkcji wina lub tworzyć zespół kilku urządzeń (czego przykładem są cztery tłocznie umieszczone w odległości $15 \mathrm{~m}$ od dwóch pras w Saint-Martin). Sok z winogron spływał do betonowego zbiornika wyłożonego dachówkami i zawsze wyposażonego w zbiorniczek do oczyszczania, a czasami także w schodki, np. w Berthoire (Pignans), Le Vigneret (Castellet). Jednak w L'Ormeau zbierano moszcz w drewnianych kadziach, w Barresse i w Tourville w glinianych doliach, a w Sivier w zbiorniku wykutym w skale. To, co zebrano, umieszczano następnie pod prasą. Kilka małych urządzeń odkrytych w L'Ormeau, Le Suveret i Tout-Égau prawdopodobnie nie miało prasy, ale możliwe też, że było wyposażonych w prasy prymitywnie skonstruowane, po których nie zachowały się pozostałości archeologiczne (deski załadowane kamieniami, płócienny worek, który się skręcał). Jeśli villa należała do bogatszych właścicieli, wówczas prasy były wyposażone w dźwignię (Brun, 2001, s. 85).

Sok winogronowy wypływał z prasy do zbiorników, takich samych jak przy tłoczni. Mieszano go i wlewano do doliów oraz pozostawiano do fermentacji, a następnie przelewano do pojemników ceramicznych pokrywanych co roku smołą, o czym można przeczytać we wszystkich zachowanych źródłach historycznych napisanych przez starożytnych agronomów. Ponieważ naczynia te umieszczano w piasku lub ziemi, w wykopanych w tym celu dołkach, smołowanie sprawiało, że stawały się wodoodporne i nie przepuszczały swojej zawartości do gruntu. Pokrycie smołą wnętrza pojemników ceramicznych sterylizowało je, pozwalało zniszczyć bakterie oraz nie dopuścić do skwaśnienia wina. Dolia lub gliniane naczynia podgrzewano na ogniu, aż sczerniały ich dna, aby ułatwić równomierne smołowanie powierzchni. Postępowano w ten sposób tylko w przypadku wina, nigdy nie przygotowywano tak pojemników ceramicznych na oliwę (Brun, 2001, s. 86).

\section{Przykładowe stanowiska archeologiczne, na których odkryto świadectwa wyrobu wina}

Najstarszym ośrodkiem produkcji wina w Galii stała się grecka kolonia Massalia (obecna Marsylia) - założona w około 600 roku p.n.e. nad zatoką Lacydon przez osadników z Fokai. Początkowo Massalczycy zajmowali się wyrobem wina na własne potrzeby, ale $\mathrm{z}$ czasem zaczęli odnosić w tej dziedzinie sukcesy, co 
zaowocowało w IV-II w. p.n.e. rozszerzeniem produkcji na większą skalę (Tchernia, Brun, s. 86-88).

Osadnicy feniccy, którzy przybyli do Galii, do zatoki Lacydon, z pewnością pili wino i doskonale znali się na uprawie winorośli, ale przypłynęli tutaj po to, aby założyć emporium handlowe. Po przybyciu na miejsce nie zaangażowali się w uprawianie winnej latorośli i wytwarzanie wina, przynajmniej nie w takim stopniu, jak w prowadzenie działalności handlowej. Dużą część grupy pierwszych osadników stanowili arystokraci feniccy. Początkowo feniccy przybysze kupowali wino od Etrusków z Vulci i Caere, którzy wcześniej niż oni zajmowali się handlem na wybrzeżu galijskim (Py, Buxo i Capdevila, 2001, s. 32).

Po wydarzeniach związanych z walkami o ekonomiczne i polityczne wpływy między greckimi kolonistami a Etruskami i Kartagińczykami, u wybrzeży Korsyki i jeszcze po kilku potyczkach terytorialnych ${ }^{4}$, ustabilizowała się sytuacja w Massalii. Przybywali do niej nowi greccy osadnicy, miasto rozrastało się. Mieszkańcy Massalii zdecydowali się na uprawianie winorośli nie tylko na własne potrzeby, ale także po to, aby produkować wino na sprzedaż. Zaczęli także wytwarzać swoje własne pojemniki ceramiczne do przechowywania wina - amfory massalskie (massaliéte). Najstarsze z nich datuje się na ostatnią ćwierć VI w. p.n.e. (Py, Buxo i Capdevila, 2001, s. 32). Rozmieszczenie znalezisk opisywanych amfor na wino datowanych na VI-V w. p.n.e. na wielu stanowiskach archeologicznych południowej Galii wskazuje na dużą skalę produkcji i rozległą dystrybucję szlakami wodnymi - wzdłuż rzek dzisiejszej Prowansji i Langwedocji i w dolinie Rodanu (Brun, 2001, s. 72). Massalia rozwijała się w szybkim tempie i na początku I w. n.e. rozszerzyła swoje terytorium. W Geografii Strabona (IV, 1, 5) można znaleźć informację o tym, że Massalczycy utrzymywali się z żeglarstwa i handlu, uprawiali winorośl i oliwki, ale ich ziemie nie były wystarczająco żyzne, aby mogło na nich rosnąć zboże, dlatego musieli wymieniać swoje produkty na pszenicę (za: Py, Buxo i Capdevila, 2001, s. 32). W VI-IV w. p.n.e. kontakty handlowe między Massalią a plemionami galijskimi z południowej Galii opierały się na wymianie wina na zboże. Jeśli nawet Galowie produkowali wino na swoje potrzeby, nie mogło się ono równać pod względem jakości z winem greckim (Py, Buxo i Capdevila, 2001, s. 42).

W ufortyfikowanych osiedlach galijskich, powstałych i funkcjonujących w czasach poprzedzonych podbojem Galii przez Rzymian, takich jak oppida w Martigues, Saint-Blaise lub Entremont (Goudineau, 1984, s. 219-221; Leveau, 2003, s. 299-308; Tchernia, Brun, 1999, s. 86-88), znaleziono prasy służące najprawdopodobniej do tłoczenia oliwy. W Martigues i Coudouneu odkryto także liczne pestki winogron datowane od $\mathrm{V}$ w. p.n.e. oraz resztki jagód winorośli poddanych tłoczeniu. Urządzenia

\footnotetext{
${ }^{4}$ W 545 roku p.n.e., po podbiciu Fokai, greckiej kolonii na zachodnim wybrzeżu Anatolii, większość jej mieszkańców zdecydowała się na przeniesienie na Korsykę i założenie tam nowej kolonii - Alalii. W 535 roku p.n.e. flota etruska i kartagińska pokonały greckich osadników - Fokajczyków pod Alalią na Korsyce. Po tej porażce i poniesionych ogromnych stratach, Fokajczycy przenieśli się na południowo-zachodnie wybrzeże Italii, gdzie ostatecznie pozostali w założonej przez siebie kolonii Elei (zob. Py, Buxo i Capdevila, 2001, s. 32).
} 
służące do wytłaczania soku z owoców z tego okresu są dość prymitywne w porównaniu z tymi używanymi w Galii rzymskiej (Tchernia, Brun, 1999, s. 86-88). Do 2001 roku opublikowano wyniki badań prowadzonych w ciągu 50 lat na stanowiskach starożytnej południowej Galii, na których znaleziono pestki winogron (próbki ponad 100 pestek winorośli uprawnej) znajdujących się w pojemnikach ceramicznych: doliach, amforach lub naczyniach gospodarczych, często wraz z pozostałościami zbóż lub warzyw. Najważniejszych odkryć dokonano na stanowiskach: Mailhac (Aude), Pierredon i Éguilles (Bouches-du-Rhône), Martigues (Bouches-du-Rhône), Coudounèu i Lançon-Provence (Bouches-du-Rhône), Le Marduel i Saint-Bonnet-du-Gard (Gard), Gailhan (Gard) oraz Lattes (Hérault) (Py, Buxo i Capdevila, 2001, s. 34-35). Większość przebadanych próbek ze stanowisk, takich jak Mailhac, Galhan, Marduel, Pierredon, ale także Beaux-de-Provence, Baou-Roux, Entremont, Mouriès, Mauressip, Nages, La Lagaste i innych tworzą pestki winogron przemieszane ze znacznie większą ilością zboża, co podaje w wątpliwość istnienie produkcji wina (Py, Buxo i Capdevila, 2001, s. 39).

W czasie, kiedy w Massalii kontynuowano produkcję wina, w Narbo (Narbonne) zajmowali się nią również rzymscy koloniści. Kolonia rzymska w Narbo została założona w 118 roku p.n.e. na ziemiach skonfiskowanych Galom. W trzeciej ćwierci I w. p.n.e. można już mówić o jej działalności gospodarczej (Tchernia, Brun, 1999, s. 86). Italscy osadnicy przybywający do Galii przynosili ze sobą kulturę picia wina, znajomość jego produkcji i uprawy winorośli (Brun, 2001, s. 72).

Najstarsze ślady uprawy winnej latorośli i pozostałości warsztatów ceramicznych wytwarzających amfory na wino przeznaczone do transportu w dolinę Rodanu pozostawione przez rzymskich osadników - datuje się na ostatnią ćwierć I w. p.n.e. Pochodzą one ze stanowisk w Saint-Martin-d'Ardèche, Sainte-Cécile-les-Vignes i Mazan (Le Jonquier, Vaucluse) (Tchernia, Brun, 1999, s. 86-88), z warsztatów garncarskich, w których produkowano imitacje italskich i hiszpańskich pojemników ceramicznych na wino w czasach panowania Oktawiana Augusta, przynajmniej na potrzeby mieszkańców kolonii w Orange (Brun, 2001, s. 72). Antyczne winnice odkryte w 1996 roku podczas prac nad budową kolejki TGV-Śródziemnomorskiej w Lapalud (Vaucluse) są prawdopodobnie starsze niż 1 połowa I w. n.e., a ich granice zazębiają się z terenem kolonii w Orange (zasiedlonej przez weteranów II Legionu) i raczej późniejszymi pozostałościami urządzeń do produkcji wina niż w wymienionych na początku stanowiskach (Tchernia, Brun, 1999, s. 86-88). Najstarsze świadectwa produkcji wina pochodzą z końca I w. p.n.e., z Arles, gdzie podczas wykopalisk ratunkowych prowadzonych w 1990 roku znaleziono pozostałości drewnianej kadzi, a w niej pestki winogronowe po wytłoczynach. Większą ilość znalezisk tego typu datuje się na początek I w. n.e. (Brun, 2001, s. 72-73)

W I w. p.n.e. doszło do wojny domowej w republice rzymskiej, walk na Półwyspie Apenińskim i poza nim, także i w Galii do ukształtowania się nowego ustroju politycznego - cesarstwa, a w konsekwencji do reorganizacji państwa rzymskiego i zmian administracyjnych, społecznych i ekonomicznych. Od końca II w. p.n.e. w Galii zaczęły powstawać kolonie rzymskie. Od połowy I w. p.n.e. prawie wszystkie 
oppida zostały stopniowo opuszczone przez zamieszkującą ją ludność, a z Półwyspu Apenińskiego sukcesywnie przybywali osadnicy italscy. Większość z nich stanowili rolnicy, którzy zamieszkiwali w wiejskich gospodarstwach. Opisywane zjawiska bardzo dobrze odzwierciedlają odkrywane warstwy archeologiczne z tego okresu, zawierające niewielką ilość znalezisk, słabo zachowane pod późniejszymi pozostałościami budynków. Na żadnym z badanych stanowisk nie znaleziono dotąd szczątków tłoczni na wino (Brun, 2001, s. 72).

W okresie cesarstwa rzymskiego produkcja wina w Galii stawała się zajęciem coraz bardziej dochodowym. Wytwarzano je na własne potrzeby oraz na sprzedaż. Gospodarstwa wiejskie zajmujące się wyrobem wina można było podzielić na dwie grupy. W pierwszej znalazłyby się villae i gospodarstwa, w których pracowali członkowie rodziny. Mieli do dyspozycji jedną tłocznię na wino i zbiornik, a oprócz produkcji wina zajmowali się również hodowlą zwierząt. Drugą grupę tworzyły większe majątki ziemskie wyposażone w kilka tłoczni na wino i zbiorniki (2-4 tłocznie, wiele doliów do przechowywania tego trunku), nastawione na wytwarzanie wina w ilościach pozwalających na czerpanie regularnych dochodów z jego sprzedaży (Brun, 2001, s. 75, 78). Poniższa tabela zawiera przykładowe stanowiska archeologiczne, które można zaliczyć do dwóch opisanych grup (Brun, 2001, s. 75-78).

\begin{tabular}{|l|l|l|l|}
\hline \multicolumn{1}{|c|}{ I grupa } & \multicolumn{1}{c|}{ II grupa } \\
\hline \multicolumn{1}{|c|}{ Stanowisko } & \multicolumn{1}{|c|}{ Datowanie } & \multicolumn{1}{c|}{ Stanowisko } & \multicolumn{1}{c|}{ Datowanie } \\
\hline $\begin{array}{l}\text { Barresse w pobliżu } \\
\text { Muy (Var) }\end{array}$ & 150-250 n.e. & $\begin{array}{l}\text { Le Grand Loou I } \\
\text { w Roquebrussanne } \\
\text { (Var) }\end{array}$ & $\begin{array}{l}\text { połowa I w. p.n.e.- } \\
\text { koniec II w. n.e. }\end{array}$ \\
\hline $\begin{array}{l}\text { Forbin w pobliżu } \\
\text { Aix-en-Provence } \\
\text { (Bouches-du-Rhô- } \\
\text { ne) - dwie villae na } \\
\text { południowy wschód od } \\
\text { Aquae Sextiae }\end{array}$ & $\begin{array}{l}\text { pierwsza villa - po- } \\
\text { łowa I w. n.e.-koniec } \\
\text { II w. n.e.; druga villa- } \\
\text { połowa I w. n.e.-koniec } \\
\text { IV w. n.e. }\end{array}$ & $\begin{array}{l}\text { Les Mesclans w La } \\
\text { Crau (Var) }\end{array}$ & $\begin{array}{l}\text { 1 połowa II w. n.e.- } \\
\text { trzecia ćwierć III w. }\end{array}$ \\
\hline $\begin{array}{l}\text { Dwa gospodarstwa } \\
\text { L'Ormeau A } \\
\text { w Taradeau (Var) }\end{array}$ & $\begin{array}{l}\text { od czasów rządów } \\
\text { Flawiuszy do końca } \\
\text { II w. n.e. }\end{array}$ & $\begin{array}{l}\text { Pardigon 3 } \\
\text { w Cavalaire-sur-Mer } \\
\text { (Var) }\end{array}$ & $\begin{array}{l}\text { ostatnia ćwierć } \\
\text { I w. n.e.-1 połowa }\end{array}$ \\
\hline $\begin{array}{l}\text { Sivier w Istres (Bo- } \\
\text { uches-du-Rhône) }\end{array}$ & I w. p.n.e.-V w. n.e. & $\begin{array}{l}\text { Rue du Port } \\
\text { w Cavalaire-sur-Mer } \\
\text { (Var) }\end{array}$ & $\begin{array}{l}\text { koniec I w. n.e. lub po- } \\
\text { czątek II w. n.e.-druga } \\
\text { ćwierć IV w. n.e. }\end{array}$ \\
\hline $\begin{array}{l}\text { Le Suveret } \\
\text { w pobliżu Saint- } \\
\text {-Raphaël (Var) }\end{array}$ & $\begin{array}{l}\text { początek I w. n.e.- } \\
\text { koniec I w. n.e. }\end{array}$ & $\begin{array}{l}\text { Saint-Martin } \\
\text { w Taradeau w Var }\end{array}$ & $\begin{array}{l}\text { 2 połowa I w. p.n.e.- } \\
\text { VI w. n.e. }\end{array}$ \\
\hline $\begin{array}{l}\text { Tout-Égau w pobliżu } \\
\text { Taradeau (Var) }\end{array}$ & $\begin{array}{l}\text { połowa I w. p.n.e.-ko- } \\
\text { niec I w. n.e. }\end{array}$ & $\begin{array}{l}\text { Les Toulons w Rians } \\
\text { (Var) }\end{array}$ & $\begin{array}{l}\text { ostatnia ćwierć } \\
\text { I w. n.e.--koniec IV lub } \\
\text { początek V w. n.e. }\end{array}$ \\
\hline & $\begin{array}{l}\text { Tourville w Saignon } \\
\text { (Vaucluse) }\end{array}$ & $\begin{array}{l}\text { II w. n.e.-2 połowa } \\
\text { III w. n.e. }\end{array}$ \\
\hline
\end{tabular}


Produkcja wina w Galii Narbonensis opierała się na sieci winnic, warsztatów garncarskich produkujących amfory na wino, położonych tak, aby można było transportować wino drogami rzecznymi i lądowymi z przeznaczeniem na rynek lokalny lub do portów morskich, a stamtąd do różnych prowincji zachodniej części imperium romanum.

Dobrym przykładem funkcjonowania opisywanej infrastruktury winiarskiej są stanowiska archeologiczne odkryte w okolicach jeziora Thau. W villi rzymskiej Prés-Bas w pobliżu Loupian (Hérault), położonej na północnym brzegu laguny Thau, wytwarzano wino w I-II w. n.e. Od lat sześćdziesiątych XX w. prowadzono w niej badania wykopaliskowe, które pozwoliły ustalić, że najstarsze ślady villi pochodzą z połowy I w. p.n.e., ale właściwy kształt przybrała ona 100 lat później. Centralną, mieszkalną część villi zajmował właściciel wraz z rodziną, zachodnią - stanowiły pomieszczenia dla służby, a wschodnią - urządzenia do wytwarzania wina (oprócz pozostałości tłoczni znaleziono także prawdopodobnie fragmenty pompy używanej do przelewania wina do zbiorników oraz około 90 doliów do przechowywania wina). W pobliżu zabudowań odkryto ślady winnicy (równoległe rzędy rowków). Całkowitą ilość wina produkowanego w villi Prés-Bas szacuje się na $1500 \mathrm{hl} \pm 250$, przy założeniu, że każde dolium było średniej wielkości, typowej dla takiego pojemnika ceramicznego. A. Tchernia obliczył, że winnice w czasach rzymskich wytwarzały 30-60 hl/ha dla powierzchni $10-50$ ha i przy dwóch winobraniach można było przechowywać zbiory w piwnicach. Niższa wydajność - 20 hl/ha (tak jak od końca średniowiecza i w czasach współczesnych) była możliwa w sytuacjach ekstremalnych i dla powierzchni około 100 ha. Działalność winnicy i produkcja wina wiąże się z amforami wytwarzanymi w warsztatach garncarskich położonych w odległości $1 \mathrm{~km}$ od nich, na brzegu jeziora Thau. Część amfor Gauloise 4 wyprodukowanych w Le Bourbou lub Port-de-Loupian miała na imadle lub szyjce stempel MAF, interpretowany jako inicjały tria nomina właściciela warsztatu (znaleziono ponad 100 egzemplarzy w tym warsztacie). Podczas jednego-dwóch wypałów wytwarzano 40 000-100 000 opisywanych pojemników ceramicznych. W piwnicy villi Prés-Bas przechowywano 4000 amfor Gauloise 4. Działalność warsztatów trwała około 100 lat, do końca ostatniej ćwierci I w. n.e. i jeszcze w II w. n.e. W 2 połowie IV w. przebudowano stary magazyn i w Le Bourbou ponownie zaczął funkcjonować warsztat garncarski produkujący amfory w okresie późnego cesarstwa - pod koniec IV w. n.e. lub w pierwszej ćwierci V w. n.e. (Buffat $\mathrm{i}$ in., 2001, s. 96-99).

Jedna z większych villi rzymskich w Galii Narbonensis - villa Molard w Donzères, wybudowana w 3 ćwierci I w. n.e. (Tchernia, Brun, 1999, s. 88-89; Jung i in., 2001, s. 115), znajduje się 15 km na północny-zachód od Saint-Paul-Trois-Châteaux (Augusty Tricastinorum - stolicy galijskiego plemienia Trikastinów), gdzie odkryto pozostałości portu na Rodanie. Zabudowania villi zajmowały $10000 \mathrm{~km}^{2}$ i zostały zbudowane w tym samym czasie na podstawie planu architektonicznego, sporządzonego tak, aby jak najbardziej usprawnić pracę i połączyć funkcjonalnie część mieszkalną z gospodarczą w jedną całość (Jung i in., 2001, s. 115-117). Villa była wyposażona $\mathrm{w}$ obszerny skład wina $\mathrm{z}$ dwoma zbiornikami do ugniatania owoców 
i czterema prasami do wytłaczania owoców, otoczonymi kadziami na otrzymywany moszcz. Centralne pomieszczenie mieściło 204 dolia, mogące pomieścić około 2500 hektolitrów wina (Tchernia, Brun, 1999, s. 88-89; Jung i in., 2001, s. 115). Położenie villi w pobliżu rzeki tłumaczy się jej znaczeniem jako ważnego ośrodka produkcji wina nastawionego na eksport. Jej czas funkcjonowania jest współczesny wielu warsztatom ceramicznym Gallii Narbonensis datowanym na połowę I w. n.e. (Jung $\mathrm{i}$ in., 2001, s. 115-117).

W I w. n.e. bardzo często galijskie prasy do owoców były wyposażone w kołowroty przymocowane na równoważącym je bloku kamiennym, tak jak w villi Toulons w Rians (Var), której piwnica na wino powstała w II połowie I w. n.e. Podobnie jak w Donzère, centralne pomieszczenie mogło pomieścić 200-300 amfor. W dwóch budynkach znajdowały się zbiorniki do ugniatania winogron, prasy do owoców i kadzie, umieszczone w północno-zachodnim i północno-wschodnim rogu magazynu. W każdym z dwóch pomieszczeń mieściły się zbiorniki do ugniatania winogron i dwie wielkie prasy zaopatrzone w dźwignię, o kształcie platformy mogącej się podnosić i opuszczać, wykonanej z masy betonowej wypełnionej kawałkami dachówek. W północnym, niżej położonym pomieszczeniu używano prasy z kołowrotem i ciężarem równoważącym jego wagę. W południowym, najniżej położonym pomieszczeniu każda z pras i każdy ze zbiorników do ugniatania owoców były otoczone czterema kadziami, do których spływał sok za pomocą ołowianych rur (podobnie jak moszcz winny gromadzony w taki sam sposób w glinianych dzbanach) (Tchernia, Brun, 1999, s. 88-89).

Ciekawych znalezisk urządzeń do wyrobu wina dostarczyły prace wykopaliskowe w Langwedocji. Odkryto je w villach rzymskich w La Domergue w Sauvian (Hérault), Loupian (Hérault) czy La Ramière w Aramon (Gard). Prace w villi La Domergue (odkrytej na początku XX w.) o powierzchni $3500 \mathrm{~m}^{2}$ w latach 1993-1994 (Tchernia, Brun, 1999, s. 88-89; Buffat $\mathrm{i}$ in., 2001, s. 94) odsłoniły zabudowania rozmieszczone wokół dziedzińca. We wschodnim skrzydle znajdowała się część mieszkalna wraz $\mathrm{z}$ termami, a w zachodnim pomieszczenia, w których wytwarzano wino (Buffat $\mathrm{i}$ in., 2001, s. 94-96). Znaleziono w nich cztery murowane kadzie, najprawdopodobniej zbiorniki do ugniatania winogron, na północ od pomieszczenia, w którym składowano wino. Możliwe, że cztery prasy do owoców zastąpiono później dwoma. Piwnica będąca składem wina, o powierzchni $198 \mathrm{~m}^{2}$, mieściła murowaną kadź oraz około 60 pojemników ceramicznych typu dolia, ale nie oddaje to liczby produkowanych naczyń z winem. Na zachód od centralnej części willi znaleziono drugi magazyn (59 m x 12,7 m powierzchni) (Tchernia, Brun, 1999, s. 89-90), który mógł pomieścić 16-32 dolia (najprawdopodobniej 27 pojemników ceramicznych). W trzecim składzie przechowywano 99-189 glinianych naczyń, czyli równowartość pojemności 163 doliów. Odkryto także pomieszczenia z pozostałościami narzędzi i tłoczni do produkcji oliwy. Zakładając, że udały się zbiory i zebrano winogrona z 500 ha, możemy przypuszczać, że we wszystkich magazynach przechowywano wówczas 63-73 ha wina (30 hl/ha), a minimalnie 31-36 ha (60 hl/ha) (Buffat i in., 2001, s. 94-96). Wyodrębniono kilka faz funkcjonowania opisywanego stanowiska. Villa istniała w I-V w. n.e., przypuszczalnie w średniowieczu już nie (Buffat i in., 2001, s. 94-96). 
Villa w Loupian, znana głównie z mozaik z Wczesnego Cesarstwa, funkcjonowała kilka stuleci. Część pomieszczeń powstała przed I w. n.e. Piwnica mierzyła 300 $\mathrm{m}^{2}$, mieściła 94 dolia o maksymalnej pojemności około 1500 hektolitrów. Były także prasy wyposażone $\mathrm{w}$ dźwignię i zrównoważone obciążeniem kamiennym. W pierwszej ćwierci II wieku n.e. część pojemników ceramicznych (dolia) przeniesiono na zewnątrz budynku. W III/IV wieku n.e. zamocowano klocki naporowe w rogu magazynu, które mogły służyć jako podparcie dla używanych w tym czasie co dolia kadzi, o czym pisał Palladiusz (IV/V w. n.e.). Budynki villi przebudowywano, a do urządzeń służących do wyrobu wina wprowadzano innowacje jeszcze w II połowie IV w. n.e. (Tchernia, Brun, 1999, s. 89-90).

Villa La Ramière w Roquemaure została odkryta w 1996 roku. Przy okazji budowy odcinka śródziemnomorskiej TGV w 1997 roku na stanowisku przeprowadzono badania archeologiczne. Najstarsze budynki zbudowano w czasie panowania Oktawiana Augusta, ale mało prawdopodobne, żeby w tym okresie zajmowano się w villi produkcją wina. W drugiej ćwierci I w. n.e. zburzono najstarsze zabudowania. We wschodniej części wybudowano budynek, który mieścił urządzenia do wytwarzania wina: tłocznie i zbiorniki. Możliwe, że w jednym z pomieszczeń przygotowywano defrutum (Buffat i in., 2001, s. 93). Znajdowały się w nim dwa kotły, które podgrzewano. Kolumella, pisząc o produkcji defrutum, opisywał podobne pomieszczenia wyposażone w kotły do gotowania wina - defrutaria (Tchernia, Brun, 1999, s. 89-90). W czasie 2 połowy I w. n.e. całość rozbudowano i powierzchnia villi osiągnęła około $5000 \mathrm{~m}^{2}$. W południowej części znajdował się magazyn na osi wschód-zachód, w którym przechowywano 24 pojemniki ceramiczne $(360 \mathrm{hl})$, o pojemności $15 \mathrm{hl}$ każdy. Drugi magazyn na osi północ-południe zbudowano prawdopodobnie między końcem I w. n.e. i początkiem II w. n.e. Mieścił 44-52 dolia o pojemności całkowitej 660-780 hl. Między końcem II w. a połową III w. n.e. nastąpił okres rozkwitu funkcjonowania villi. Piwnica z wcześniejszego okresu nie była użytkowana po III w. n.e. Jeszcze w IV w. istniały wielkie magazyny, ale nie znaleziono na tyle pewnych śladów archeologicznych, żeby można było mówić o kontynuacji produkcji wina w późnej starożytności (Buffat $\mathrm{i}$ in., 2001, s. 93-94).

W Berthoire w pobliżu Pignans (Var) w czasie wykopalisk prowadzonych na zachodnim krańcu wsi odkryto pozostałości osadnictwa rzymskiego: małe termy publiczne, sklepy i 5 domów, które znajdowały się z jednej i drugiej strony drogi łączącej Forum Voconii z Telo Martius (Toulon). Zostały zbudowane pod koniec I w. n.e. i były użytkowane do połowy III w. n.e. W budynkach mieszkalnych znaleziono pozostałości urządzeń do wyrobu wina: tłocznię na wino wyposażoną w dźwignię, wybetonowany zbiornik oraz dolia. Dźwignie prasy poruszały się dzięki linom biegnącym do kamiennych ciężarków jako przeciwwagi i umieszczonych w czworokątnych dołkach. Produkcja wina każdego wytwórcy była mała: jeden miał 3 dolia o maksymalnej pojemności $45 \mathrm{hl}$, a drugi kolejne 10 o pojemności 100-150 hl. Wymieniona ilość mogła być większa, jeśli założymy, że wino przechowywano także w drewnianych beczkach. Beczki nie były używane tylko do transportu wina. Pokrywę jednej z nich znaleziono w wypełnisku jamy datowanej na 1 połowę III w. n.e. (Brun, 2001, s. 73-75). 
P. Bossinot, podsumowując stan badań archeologicznych przeprowadzonych do 1999 roku na obszarze dawnej Galii Narbonensis, wymieniał 32 najważniejsze stanowiska będące winnicami z czasów rzymskich i przedrzymskich (Boissinot, 2001, s. 45-68). Regularnie prowadzone prace wykopaliskowe od lat pięćdziesiątych do czasów współczesnych pozwoliły w bardzo dużym stopniu przebadać pozostałości rzymskiej i galo-rzymskiej sieci osadniczej. Dużą część objętych badaniami archeologicznymi stanowisk stanowiły starożytne villae i gospodarstwa wiejskie z winnicami, których właściciele zajmowali się uprawą winorośli i produkcji wina ${ }^{5}$.

Są one zróżnicowane pod względem wielkości zajmowanej powierzchni, ilości i rodzaju urządzeń do wyrobu wina oraz możliwości produkcyjnych. Różnią się także długością funkcjonowania. Mniejsze winnice bywały opuszczane przez właścicieli i przejmowane przez bardziej dynamicznych posiadaczy ziemskich, tak jak miało to miejsce np. w Le Suveret i Tout-Égau przed końcem I w. n.e. (Brun, 2001, s. 87). Jedną z najstarszych, antycznych winnic odkrytych na ziemiach dawnej Galii jest Saint-Jean-du-Désert znajdująca się $4 \mathrm{~km}$ na wschód od historycznego centrum Marsylii. Prace wykopaliskowe prowadzone od 1992 roku umożliwiły określenie chronologii tego stanowiska na IV-II w. p.n.e. (okres hellenistyczny). Winnica była także użytkowana w II w. n.e. (w okresie gallo-rzymskim) (Boissinot, 2001, s. 58-59).

W Gasquinoy, w pobliżu Béziers, odkryto dwa małe gospodarstwa zajmujące się produkcją wina $\mathrm{w}$ I-II w. n.e. W każdym $\mathrm{z}$ nich mieściła się mała piwnica na dolia (27 i 12 sztuk), 1 lub 2 zbiorniki, studnia i fragmenty tłoczni na wino. Zabudowania obu gospodarstw są położone w odległości około $200 \mathrm{~m}$ od siebie i otoczone pozostałościami winnicy (o czym świadczą ślady dołków i rowów), której powierzchnię szacuje się na 15 ha. Przebadano archeologicznie 20 ha. W obu studniach znaleziono szczątki nasiąkniętych wodą winorośli. Obecność pozostałości wytłoczyn, skórek winogron, pestek i fragmentów łodyg wyraźnie wskazuje na wytwarzanie wina w obrębie opisywanych stanowisk archeologicznych (Bouby i in., 2010, s. 130-131).

Prace archeologiczne prowadzone przy okazji budowy autostrady A75 pozwoliły odsłonić pozostałości villi La Quintarié w Clermont-l’Hérault (Hérault) datowanej na

\footnotetext{
${ }^{5}$ Przykładowe stanowiska winnic rzymskich i przedrzymskich: Aix-en-Provence (Zac Sextius-Mirabeau z II w. n.e. i Signoret z wczesnego cesarstwa), Alleins (Derrière Saint-Pierre - nieokreślona chronologia, starożytność, Jardinets-Pierrefeu - wczesne cesarstwo, Jonquerolles - starożytność, Tamberlette - I w. n.e.), Marseille (Alcazar - późna starożytność, Saint-Jean-du-Désert - IV-II w. p.n.e.), Les Pennes-Mirabeau (Vallon de Bellepeire - późna starożytność?), Ventabren (Les Bosques - wczesne cesarstwo, Château-Blanc - wczesne cesarstwo), Vernègues (Montée du Gancel - wczesne cesarstwo), Nîmes (Le Florian II-I w. p.n.e., Îlot Thérond I w. p.n.e., Îlot Grill okres Republiki rzymskiej, Rue Émile-Jamais II-I w. p.ne., ZAC des Halles II w. p.n.e., ZAC du Forum des Halles II w. p.n.e. - I w. n.e., Saint-André-de-Codols wczesne cesarstwo, Le-Viol-du-Plan okres Republiki rzymskiej, Le Mas Carbonnel II w. p.n.e. i wczesne cesarstwo), Hérault (Béziers - Le Garrisou - starożytność, Clermont-l'Hérault: La Quintarié wczesne cesarstwo, Lattes: Port-Ariane - późna epoka żelaza, Lunel: Dassargues - wczesne cesarstwo, Lunel-Viel: Village wczesne cesarstwo, Montpellier: Les Cauquillous najwcześniej w I w. p.n.e., Mudaison: Les Plantiers I-II w. n.e., Sauvian: La Domergue wczesne cesarstwo), Var (Tavernes: Roure-Gros starożytność?), Vaucluse (Lapalud: Les Girardes - wczesne cesarstwo, Les Dèves - wczesne cesarstwo) (zob. Boissinot, 2001, s. 63-68).
} 
75-140 rok n.e. Na przebadanej powierzchni 25 ha odkryto zabudowania i winnicę. Znajdowały się one przy skrzyżowaniu dwóch starożytnych rzymskich dróg. Całość kompleksu składała się z 3 grup budynków zajmujących powierzchnię $4500 \mathrm{~m}^{2}$. Jedną z nich tworzyły budowle $\mathrm{z}$ urządzeniami do wyrobu wina. W piwnicy odkryto 4 zbiorniki, które zbudowano w różnym czasie, szczątki tłoczni z kołowrotem (możliwe, że była to śruba), 40 doliów na wino (24-28 z nich było używanych jednocześnie, każde dolium o średniej pojemności 12-15 hl, zaś pojemność piwnic wynosiła 288$420 \mathrm{hl}$ ). W I w. n.e. - początku II w. n.e. zasadzono szczepy winorośli, czego śladem jest 40 rowów odkrytych na $80 \mathrm{~m}^{2}$. Przeciętna winnica o powierzchni 7-14 ha mogła wytwarzać 30-40 hl wina, zakładając, że zbiory się udały. Prawdopodobnie dwa małe wiejskie gospodarstwa Les Garels w Brignac i Fouscaïs w Clermont-l'Hérault, funkcjonujące w tej samej epoce, oddalone od siebie o 600-700 $\mathrm{m}$ i położone w pobliżu opisywanej villi mogły być zaangażowane w rozwój należącej do niej ogromnej winnicy (Buffat i in., 2001, s. 99-101; Boissinot, 2001, s. 60-61).

\section{PODSUMOWANIE}

Plemiona celtyckie, które zamieszkiwały Galię, przed przybyciem Rzymian nie uprawiały winorośli i nie produkowały wina. Kupcy greccy, a później etruscy sprowadzali do niej greckie i italskie wino, a greccy koloniści w IV-II w. p.n.e. jako pierwsi założyli winnice i sprzedawali wino własnego wyrobu ludności galijskiej. W okresie od II w. p.n.e. do końca I w. p.n.e. Rzymianie zmonopolizowali handel winem w Galii, ponieważ w czasach Republiki rzymskiej Italia stała się najważniejszym producentem wina w zachodniej części basenu Morza Śródziemnego. W ostatnich dziesięcioleciach p.n.e. zaczęto wytwarzać rodzime wino galijskie. W I w. n.e. nie mogło ono jeszcze konkurować pod względem skali produkcji i sprzedaży z hiszpańskim winem z Hispanii Tarraconensis, które zmonopolizowało nie tylko rynek Galii, ale importowano je na masową skalę w zachodnich prowincjach cesarstwa rzymskiego. Od połowy/końca I w. n.e. do końca II w. n.e. Gallia Narbonensis zdominowała handel winem tak jak wcześniej Italia i Hiszpania. W jej warsztatach garncarskich produkowano na masową skalę amfory, w których sprzedawano wino w całej Galii i zachodniej części basenu Morza Śródziemnego, a uprawa winorośli stała się jedną z ważniejszych gałęzi rolnictwa. Potwierdzają to liczne znaleziska archeologiczne odkryte na stanowiskach lądowych i podwodnych?

\footnotetext{
${ }^{6}$ Jedna z nich mogła łączyć Cessero (Saint-Thibéry, Hérault), wzdłuż Via Domitia, Luteva (Lodève, Hérault) i Condatomagus (Millau, Aveyron).

${ }^{7}$ M.in. stanowiska z rejonu Langwedocji - warsztaty ceramiczne w: Aspiran (Hérault), Bagnols-sur-Cèze (Gard), Corneilhan (Hérault), Chusclan (Gard), Fréjus (Var), Istres (Bouches-du-Rhone), Laurens (Hérault), Meynes (Gard), Montans (Tarn), Montbazin (Hérault), Nîmes (Gard), Sainte-Cécile-les-Vignes (Vaucluse), Sainte-Côme i Maruejols (Gard), Saint-Gilles (Gard), Saint-Laurent des Arbres (Gard), Saint-Marcel (Aude), Salleles d'Aude (Aude), Sauveterre (Gard), Servian (Hérault), Sigean (Aude), Tressan
} 
Właściciele winnic samodzielnie lub przez pośredników poszukiwali nabywców swoich trunków albo przed zakończeniem produkcji ustalali z konkretnym kupcem zakup całej partii wina. Wino kupione w winnicy mogło znajdować się w amforach należących do właściciela winnicy lub w amforach przywiezionych ze sobą przez kupca, ale także zostać sprzedane „luzem” do najbliższych miast, gdzie przelewano je do amfor i eksportowano dalej rzecznymi lub morskimi statkami. Znamy przynajmniej dwa przykłady świadczące o stosowaniu ostatniej możliwości transportu. W wielkiej posiadłości - villi Toulons w Rians - nie produkowano amfor. Można to wytłumaczyć bliskością rzeki Durance. Wino umieszczano w skórzanych workach i wieziono wozami na jej brzeg, gdzie następnie sprzedawano. W dolinie L'Argens liczne villae (np. Saint-Martin, L'Ormeau w Taradeau, Le Suveret i Roussiveau w Saint-Raphaël, Villepey i Saint-Aygulf we Fréjus) prawdopodobnie nie posiadały własnych warsztatów garncarskich. Wino zakupione przez kupców musiało być przelewane w amfory w porcie we Fréjus. W tych okolicach funkcjonowało dużo warsztatów ceramicznych (np. w Le Pauvadou, Saint-Lambert, La Madeleine). Przypomina to sytuację handlu oliwą w Betyce, gdzie transportowano oliwę „luzem” aż do warsztatów garncarskich znajdujących się na wybrzeżu rzeki, blisko punktów przeładunku do łodzi, skąd oliwa umieszczona $\mathrm{w}$ amforach była przewożona dalej drogami rzecznymi i morskimi (Brun, 2001, s. 86). Galijskie wino eksportowano drogami lądowymi, szlakami rzecznymi i morskimi w amforach typu: Gauloise 1, Gauloise 2, Gauloise 3, Gauloise 4 i Gauloise 5, rzadziej w amforach wzorowanych na italskich i hiszpańskich: Dressel 1 - Pascual 1 i Dressel 2-4 ${ }^{8}$.

Uprawa winorośli i produkcja wina rozpowszechniła się na tyle wśród rolników w prowincjach rzymskich, że winobranie stało się jedną z typowych czynności w wielu wiejskich gospodarstwach, czego przykładem jest Galia. Brama Marsa w Reims datowana na 1 połowę III w. n.e. ilustruje kalendarz podstawowych zajęć rolniczych. Na sklepieniu wyrzeźbiono prace rolnicze przypadające na poszczególne miesiące roku. I tak w czerwcu pokazano rozmnażanie koni, w lipcu sianokosy i żniwa, w sierpniu zbieranie owoców i zwożenie słomy, we wrześniu polowania i jesienną orkę, w październiku młócenie i wyciskanie winogron i w listopadzie przygotowywanie i układanie zapasów zimowych, w tym wina (Tchernia, Brun, 1999, s. 74). Dzięki zachowanym źródłom historycznym i archeologicznym możemy odtworzyć realia towarzyszące produkcji wina w czasach rzymskich oraz samą technologię wytwarzania tego trunku. Rzymska prowincja Gallia Narbonensis stanowi doskonały przykład obszaru ze sprawnie funkcjonującą infrastrukturą winiarską, dzięki której wykształciła się tam kultura picia wina.

(Hérault), Tresques (Gard), Velaux-Moulin du Pont (Bouches-du-Rhone) (zob. Laubenheimer, red., 1992; Laubenheimer, 1985).

${ }^{8}$ Opisywane pojemniki ceramiczne produkowano na obszarze obecnej Langwedocji (Gauloise 2, Gauloise 3, Gauloise 4) i Prowansji (Gauloise 1, Gauloise 2, Gauloise 3, Gauloise 4, Gauloise 5) (zob. Laubenheimer, red., 1992; Laubenheimer, 1985). 


\section{BIBLIOGRAFIA}

Boissinot, P.

2001 Archéologie des vignobles antiques du sud de la Gaule. Gallia, 58, 45-68.

Bouby, L. $\mathrm{i}$ in.

2010 La vigne sauvage (Vitis vinifera subsp. sylvestris): une plante cultivée dans les établissements viticoles de la Narbonnaise? W: C. Delhon, I. Théry-Parisot, S. Thiébault (red.), Des hommes et des plantes. Exploitation du milieu et gestion des ressources végétales de la préhistoire à nos jours. XXXe rencontres internationales d'archéologie et d'histoire

Brun, J.-P. d'Antibes (s. 129-139). Antibes: Éditions APDCA.

2001 La viticulture antiqua en Provence. Gallia, 58, 69-89.

Buffat, L., Pellecuer, Ch., Mauné, S., Pomarèdes, H.

2001 La viticulture antique en Languedoc-Roussilon. Gallia, 58, 91-111.

Goudineau, Ch.

1984 Un contrepoids de pressoir à huile d/Entremont (Bouches-du-Rhône). Gallia, 42, 219221 .

Greene, J. A.

1996 The Beginnings of Grape Cultivation and Wine Production in Phoenician/Punic North Africa. W: P. E. McGovern, S. J. Fleming, S. H. Katz (red.), The Origins and Ancient History of Wine (s. 311-322). Amsterdam: Gordon and Breach.

Hedberg, S., Lundström, V., Josephson, Á. (red.).

1968 Lucius Iunius Moderatus Columella, L. Iuni Moderati Columellae Rei Rusticae liber XII, ks. XII, 16, 18-34, s. 30-53. Uppsala - Göteborg: Almqvist \& Wiksell.

Jung, C. $\mathrm{i}$ in.

2001 La viticulture antique dans le Tricastin (moyenne vallée du Rhône). Gallia, 58, 113-128.

Laubenheimer, F. (red.)

1992 Les amphores en Gaule. Production et circulation. Besançon: Presses universitaire de Franche-Comté.

Laubenheimer, F.

1985 La production des amphores en Gaule Narbonnaise. Paris: Les Belles Lettres.

Leveau, $\mathrm{Ph}$.

2003 L'oléiculture en Gaule Narbonnaise: données archéologiques et paléoenvironnemtales.

Présentation - Interprétation. Revue archéologique de Picardie, 1-2, 299-308.

Mikołajczyk, I. (przekł).

1991 Lucjusz Juniusz Moderatus Kolumella, O rolnictwie, 2, ks. XII, 16, 18-34, (s. 152-172).

Toruń: Wydawnictwo Adam Marszałek.

Py, M., Buxo i Capdevila, R.

2001 La viticulture en Gaule à l’Âge du Fer. Gallia, 58, 29-43.

Sáez Fernandez, P.

1999 El vino en las fuentes históricas romanas. W: Simposio de arqueología del vino. El vino en la antigüedad romana (Jerez 2-4 octubre 1996) (s. 35-50). Madryt: Universidad Autónoma de Madrid.

Świderkówna, A. (red.).

1990 Stownik pisarzy antycznych. Warszawa: Wiedza Powszechna.

Tchernia, A., Brun, J.-P.

1999 Le vin romain antique. Grenoble: Glénat. 


\section{WINE AND THE WINES PRODUCTION TECHNOLOGY IN GALLIA NARBONENSIS IN THE 2ND CENTURY BC B.C. - 2ND CENTURY A.D.}

\section{Sum mary}

Greek and Roman literature informs about wine, grapevine and its cultivation. Attempts to recreate the winemaking process are based not only on written sources, but also on archaeological finds, such as the remains of wine presses, fruit presses and vats, as well as tanks for must and wine juice, as well as amphorae for storing this wine (Gauloise 1, Gauloise 2, Gauloise 3, Gauloise 4 and Gauloise 5, less often based on Italian and Spanish: Dressel 1 - Pascual 1 and Dressel 2-4).

The Celtic tribes that inhabited Gaul before the arrival of the Romans did not grow vines and did not produce wine. Greek and later Etruscan merchants brought Greek and Italian wine to it, and only Greek colonists in the 4th-2nd century BC were the first to establish vineyards and sell their own wine to the Gaulish people. The oldest center of wine production in Gaul was the Greek colony of Massalia (Marseille). Greek colonists and then Roman settlers began to grow grapevines and produce wine for local needs. Narbo (Narbonne) became the first Roman colony to which newcomers from Italy brought with them the culture of drinking wine, the knowledge of its production and viticulture. During the Roman Empire, wine production in Gaul became an increasingly profitable occupation, and Gallia Narbonensis from the mid / late 1st century AD until the end of the 2nd century AD dominated the wine trade in the western Mediterranean, as did Italia and Spain before.

The production of wine was done both in large estates and in small family farms, which we know from the numerous archaeological discoveries of production centers equipped with various devices and often associated with specific ceramic workshops producing amphoras for its storage. The quality of wine and the methods of its production have changed from generation to generation. A. Tchernia calculated that the Gallic vineyards in Roman times produced 30-60 hectares per hectare for an area of 10-50 hectares, and with two grapevines it was possible to store the harvest in cellars. Lower productivity $-20 \mathrm{hl} / \mathrm{ha}$ (as from the end of the Middle Ages and in modern times) was possible in extreme situations and for an area of about 100 ha. However, it was not the Greeks who started wine production, but the people of the Middle East.

The beginnings of grapevine cultivation in present-day Iran and the Caucasus date back to 5,000 years BC. The wine making technology was gradually improved and spread to other areas. Grapes were placed in clay jugs, left to ferment, they were kneaded with their feet in rock or brick pools or by using the so-called "twisting press" to obtain the juice of the grape must. In Crete, Cyprus and Greece, presses were used equipped with a lever, a wooden log, later assisted by a winch. The Romans took over the production of wine from the Greeks. In Italy during the Roman Republic, the second turnstile became a counterweight to the second turnstile.

From the 2 nd half of the 1 st century BC turnstiles were gradually replaced with screws. In the early Roman Empire, this type of pressing plant was not known and used in all its regions. In Africa, screw presses have never been used, unlike in Gaul, where these machines have become very popular. In the 1st-2nd century AD in Gaul Narbonensis, wine was produced using two types of wine presses: equipped with a lever and a winch (also used during the Roman Republic) and operating thanks to a lever with a counterweight and a winch, and in the 3rd century AD stamping press with screw. Presses with a lever and counterweight were easily transformed into presses equipped with a screw (the winch was replaced with a screw). The Roman province of Gallia Narbonensis is an excellent example of an area with a well-functioning wine infrastructure which has developed a wine-drinking culture there. 